\title{
Introduction: EU consumer and contract law at a crossroads?
}

Christian Twigg-Flesner

\section{A RESEARCH HANDBOOK ON EU CONSUMER AND CONTRACT LAW - WHY NOW?}

In this Research Handbook, legal scholars from around the European Union examine a range of aspects of EU consumer and contract law. Some of the contributions provide a general survey of the current state of the law, ${ }^{1}$ others examine general themes which can be identified in the current state of the law, ${ }^{2}$ and some take a forward-looking perspective as to where things might go in the future. ${ }^{3}$ Taken together, these chapters provide a range of useful perspectives on the current state of development of this key area of European private law, published at a point in time in the story of EU consumer and contract law where it has arrived at a crossroads, with some uncertainty as to how the story may continue. Many of the contributions in this Research Handbook offer a range of suggestions for what may follow, whether about reforms and adjustments to the current law (for example, Chapter 10 on information duties) or with regard to more fundamental issues (for example, Chapter 20 on developing a theoretical framework, or Chapter 24 exploring the various dimensions of the future of EU contract law). This Research Handbook will provide both a comprehensive survey of this area of law for the novice researcher and fresh food-for-thought for scholars who have been researching this area of law for many years.

\footnotetext{
1 Chapters 1, 9 and 11-18 on EU consumer law, and Chapter 19 on EU contract law.

2 Chapters 2-8 and 22-23.

3 Chapters 10, 20-21 and 24.
} 


\section{THE STORY OF EU CONSUMER AND CONTRACT LAW - A TRAGEDY IN FOUR ACTS}

To provide the context for this Research Handbook, a brief account of the evolution of EU Consumer and Contract Law is provided below.

\section{Act 1: The Development of EU Consumer Law}

The origins of EU Consumer Law are found in a Council Resolution of 1975,4 in which the Member States acknowledged the importance of consumers to the successful completion of the Single Market. The mid-1980s saw the enactment of two important directives: those on misleading advertising ${ }^{5}$ and on door-step selling. ${ }^{6}$ The latter, in particular, was noteworthy because it was not only the first directive which affected consumer contracts, but also because it utilised what have become the two stalwarts of EU consumer law: the right for a consumer to withdraw from a contract, and the obligation on a trader to provide specific information (although in this instance, limited to the existence of the consumer's right of withdrawal). ${ }^{7}$ It is well-known that subsequent directives gradually increased the volume of information which a trader would be required to provide to a consumer, both in specific directives such as those in the field of travel law ${ }^{8}$ (package travel ${ }^{9}$ and timeshare), ${ }^{10}$

4 Council Resolution of 14 April 1975 on a preliminary programme of the European Economic Community for a consumer protection and information policy OJ 1975 C92/1.

5 Directive 84/450/EEC relating to the approximation of the laws, regulations and administrative provisions of the Member States concerning misleading advertising - OJ 1984 L250/1.

6 Directive 85/577/EEC to Protect the Consumer in Respect of Contracts Negotiated Away From Business Premises - OJ 1985 L372/31. A second directive in the field of consumer law adopted in 1985 was the Product Liability Directive (Directive 85/374/EEC on the approximation of the laws, regulations and administrative provisions of the Member States concerning liability for defective products OJ 1985 L210/29), but as this Directive does not focus on contract law, it is not considered further in this Research Handbook.

7 These are discussed in depth by Christoph Busch in Chapter 10 (information duties) and Jonathon Watson in Chapter 11 (withdrawal rights).

8 See Chapter 16 (Josep Maria Bech Serrat).

9 Directive 90/314/EEC on package travel, package holidays and package tours OJ $1990 \mathrm{~L} 158 / 59$.

10 Directive $94 / 47 / \mathrm{EC}$ on the protection of purchasers in respect of certain aspects of contracts relating to the purchase of the right to use immovable 
as well as the more general Distance Selling Directive. ${ }^{11}$ The focus on providing information rather than detailed substantive regulation of consumer contracts is, at least in part, the result of the specific image of the consumer developed by the Court of Justice of the European Union (CJEU) - the notion of the 'reasonably circumspect and well-informed consumer' ${ }^{12}$ This provided a rationale for mandating traders to provide information, and also partially justified the introduction of the right to withdraw from a contract in certain circumstances. ${ }^{13}$ Nevertheless, whilst the requirements to provide more and more information and to grant consumers a right of withdrawal in certain situations have been widely used in EU consumer law measures, there have been two important directives which are concerned with the substantive regulation of consumer contracts: the Unfair Contract Terms Directive, ${ }^{14}$ and the Consumer Sales Directive. ${ }^{15}$

These directives generally followed a 'minimum harmonisation' approach, laying down a baseline level of consumer protection below which the national laws of the Member States could not go, but it also left Member States free to retain or introduce legal rules which gave consumers greater protection than required by a directive. In addition, directives generally only covered selected aspects of the area they regulate - for example, the Consumer Sales Directive does not contain any provisions on damages and consequential losses. The minimum harmonisation character and the piecemeal ('pointillist' ${ }^{16}$ ) approach of

properties on a timeshare basis OJ 1994 L280/83, subsequently replaced by Directive 2008/122/EC on the Protection of Consumers in Respect of Certain Aspects of Timeshare, Long-Term Holiday Product, Resale and Exchange Contracts - OJ 2009 L33/10.

11 Directive 97/7/EC on the Protection of Consumers in Respect of Distance Contracts OJ 1997 L144/19.

12 See Chapter 9 (Peter Cartwright) and also H Unberath and A Johnston, 'The double-headed approach of the ECJ concerning consumer protection' (2007) 44 Common Market Law Review 1237.

13 The rationales are discussed more fully by Jonathon Watson in Chapter 11.

14 Directive 93/13/EEC on unfair terms in consumer contracts OJ 1993 L95/29. See Chapter 13 (Peter Rott) for a discussion of the Directive and the extensive body of CJEU case law which has built up over the decades.

15 Directive 99/44/EC on certain aspects of the sale of consumer goods and associated guarantees OJ L 171/12. An overview is given in Chapter 12 by Rick Canavan.

16 WH Roth, 'Transposing 'Pointillist' EC Guidelines into Systematic National Codes - Problems and Consequences' (2002) 6 European Review of Private Law 761. 
these directives created difficulties for many Member States when it came to transposing these directives - particularly those with a civil code. In some countries, directives were transposed in separate pieces of legislation, whereas others attempted to integrate the consumer-specific contract law rules into their civil codes. ${ }^{17}$ In the UK, on the other hand, this question was less acute, and directives have generally been implemented through discrete legislation. Changes to existing legislation to integrate rules from a directive were only made in a few instances (Timeshare and Consumer Sales).

The consequences of this approach to making EU Consumer Law were two-fold: first, the minimum harmonisation approach meant that there was still a significant degree of variation between the consumer laws of the Member States; and secondly, the gradual and piecemeal adoption of directives over many years meant that these lacked coherence: for example, the definitions of key concepts such as 'consumer' or 'seller' varied, as did the rules on withdrawal rights found in various directives. The European Commission-sponsored EC Consumer Compendium project ${ }^{18}$ examined the implementation of eight consumer law directives across the 28 Member States, together with relevant national case law and showed how much levels of consumer protection continued to differ across the EU. In order to pursue both greater coherence and closer approximation, the Commission put forward its proposal for a Consumer Rights Directive, which would have merged the directives on doorstep and distance selling, unfair terms and consumer sales, and would have adopted a 'maximum harmonisation' approach. Scholars debated this proposal extensively, both its substantive content and the policy shift towards maximum harmonisation. ${ }^{19}$ It is particularly noteworthy that there was considerable scepticism about a broad maximum harmonisation approach, with few legal scholars in favour. ${ }^{20}$ At best, targeted maximum harmonisation of selected aspects might be acceptable, but not the broad

17 For the German experience, see Fryderyk Zoll's account in Chapter 3, and the particular challenges posed by the terminology of EU directives, see Chapter 6 (Barbara Pozzo).

18 H Schulte-Nölke, C Twigg-Flesner and M Ebers, EU Consumer Law Compendium (Sellier, 2008).

19 See e.g., M Faure, 'Towards maximum harmonization of consumer contract law?!?' (2008) 15 Maastricht Journal 433; P Rott, and E Terryn, 'The proposal for a directive on consumer rights: no single set of rules' (2009) 17 Zeitschrift für Europäisches Privatrecht 456.

20 One notable exception being E Hondius, 'The proposal for a European directive on consumer rights: a step forward' (2010) 18 European Review of Private Law 103. 
sweep proposed by the Commission. ${ }^{21}$ In many ways, scholarly criticism foreshadowed the political fate of the Consumer Rights Directive, and after almost three years of negotiations, the final version of the Consumer Rights Directive ${ }^{22}$ essentially only standardised pre-contractual information duties and the right of withdrawal; however, the directives on unfair contract terms and consumer sales escaped without any substantive amendments. It also left the Commission's plans for the core of consumer contract law in tatters, with maximum harmonisation not finding sufficient support among the Member States (although some success had previously been had with some directives in the financial services area ${ }^{23}$ as well as the important Directive on Unfair Commercial Practices ${ }^{24}$ ).

\section{Act 2: The Emergence of European Contract Law}

In parallel to the development of EU Consumer (Contract) Law, the debate about European Contract Law generally ${ }^{25}$ was launched in early 2001 with the Commission's Communication on European Contract Law. ${ }^{26}$ It emerged as a new focus for legal scholarship, ${ }^{27}$ and there is now a vast amount of literature on this area - indeed, Thomas Wilhelmsson observed more than a decade ago that writings on European contract law have 'become so voluminous that it seems impossible to follow in all its details', ${ }^{28}$ an observation which is even more true today. Further communications from the Commission followed in 2003 (A More Coherent European Contract Law - An Action Plan) ${ }^{29}$ and 2004 (European

21 E.g., H Micklitz, and N Reich, 'Crónica de una muerte annunciada: the Commission proposal for a "directive on consumer rights" (2009) 46 Common Market Law Review 471.

22 Directive 2011/83/EU on Consumer Rights OJ 2011 L304/64.

23 On financial services, see Chapter 14 (Vanessa Mak).

24 See Chapter 17 (Willem van Boom).

25 For an overview, see Chapter 19 (Hugh Beale).

26 COM (2001) 398 final, 11 July 2001. See also 'On the way to a European contract code?' (editorial comments) (2002) 39 Common Market Law Review 219-255.

27 For general overviews, see L Miller, The Emergence of EU Contract Law - Exploring Europeanization (Oxford University Press, 2011) or C TwiggFlesner, The Europeanisation of Contract Law, 2nd edn (Routledge, 2013).

28 T Wilhelmsson, 'The ethical pluralism of late modern Europe and codification of European contract law' in J Smits (ed.), The Need for a European Contract Law (Groningen: Europa Law Publishing, 2005), 123.

29 COM (2003) 68 final. 
Contract Law and the revision of the acquis: the way forward). ${ }^{30}$ From these emerged the plan to create a so-called 'Common Frame of Reference' on European contract law, conceived of as a toolbox containing principles and rules of contract law which could be utilised for drafting future contract law measures. It is well-known that the Common Frame of Reference project was a major scholarly exercise, and over a period of four years, the so-called Draft Common Frame of Reference (DCFR) was produced. This provided a statement of general principles, model rules, explanatory commentary on each rule, and national law notes comparing the model rules with the national laws of the EU Member States. The final product was published in six volumes and runs to 6,600 pages. ${ }^{31}$ It covered much more than just contract law, which left it open to criticism - the DCFR looked like a blueprint for a European Civil Code, something which had far from universal support. In 2010, the Commission consulted on a range of policy options for the next step, ${ }^{32}$ and also set up an Expert Group to produce a Common Frame of Reference on contract law from the DCFR. ${ }^{33}$ This soon led towards the proposal for a Common European Sales Law.

\section{Act 3: The Proposal for a Common European Sales Law}

The European Commission's proposal for a Common European Sales Law (CESL) $)^{34}$ in October 2011 was the culmination of a decade's work. ${ }^{35}$ The Commission proposed to use a Regulation to introduce a second set of contract law rules into the laws of the Member States, which parties could opt into instead of the otherwise applicable national

30 COM (2004) 651 final, 11 October 2004. See D Staudenmeyer, 'The way forward in European contract law' [2005] European Review of Private Law 95-104.

31 Study Group on a European Civil Code/Research Group on the Existing EC Private Law (Acquis Group) (eds) Principles, Definitions and Model Rules on European Private Law - Draft Common Frame of Reference (OUP, 2010).

32 Green Paper on Policy Options for Progress towards a European Contract Law for Consumers and Businesses COM (2010) 348 final.

33 Commission Decision setting up the Expert Group on a Common Frame of Reference in the area of European Contract Law OJ 2010 L105/109.

34 COM (2011) 635 final, 11 October 2011. See e.g., M Schmidt-Kessel (ed.), Ein einheitliches europäisches Kaufrecht? (Sellier, 2012); H SchulteNölke, F Zoll, N Jansen and R Schulze (eds), Der Entwurf für ein optionales europäisches Kaufrecht (Sellier, 2012).

35 See Chapter 19 (Hugh Beale) and Chapter 20 (Esther Arroyo Amayuelas). 
law rules. ${ }^{36}$ There were several differences compared to the harmonisation approach that had been pursued in the area of EU (Consumer) Contract Law until then: first, the proposal was in the form of a Regulation, which - unlike the directives making up the bulk of EU consumer law - does not require transposition into national law to take effect - a Regulation is directly applicable. Second, CESL would have been optional, that is, parties could have chosen whether to enter into a contract under the European rules or the applicable national law. Third, it would have been available for contracts for the sale of goods or digital content where one party is a business and the other either a consumer or a small/medium-sized enterprise, which would have been the first major initiative in the field of commercial contract law. Finally, the scope of application for CESL would have been limited to cross-border contracts only.

Nevertheless, CESL was not received favourably throughout the EU. Several Member States objected on the basis of subsidiarity, claiming that the EU had not made out a sufficient case to justify action at the European level. The European Parliament did scrutinise the proposal and proposed a range of amendments, but in December 2014, the European Commission decided to withdraw the proposal for CESL. After almost 15 years of work on European contract law, there was very little to show for it: there was no Common Frame of Reference, no toolbox (the Consumer Rights Directive, once regarded as vehicle to test the model rules the Common Frame of Reference should have provided, had been adopted without drawing on the model rules in the DCFR), and not even a narrow optional instrument for cross-border sales contract.

\section{Act 4: Will the Digital Single Market Come to the Rescue of EU Consumer and Contract Law?}

Although the withdrawal of CESL in December 2014 might have suggested that there would be a period of inaction in the field of EU consumer and contract law, there were soon indications that there would be a new initiative in the context of one of the European Commission's priority areas: the Digital Single Market. In early May 2015, the European Commission published its Digital Single Market Strategy ${ }^{37}$

\footnotetext{
36 On the complexities of identifying the law applicable to a contract and related private international law issues, see Chapter 7 (Lorna Gillies).

37 European Commission, Communication on a Digital Single Market Strategy for Europe COM (2015) 192 final, available 5 April 2016 at http://ec.europa. eu/priorities/digital-single-market/docs/dsm-communication_en.pdf.
} 
setting out a number of proposed actions. The gist of these is that the EU would establish a legislative and regulatory framework for maximising the opportunities offered by the digital environment for the Single Market in the EU. Its overall objective would be to create a level playing field throughout the EU for conducting business in the digital world. This would include improved EU data protection rules and steps to prevent geo-blocking.

Crucially for the present work, there is a plan to modernise consumer protection rules for online and digital purchases, that is, to improve protection for consumers when buying goods online as well as when acquiring digital products. The Commission indicated that there would be two proposals: the first would deal with harmonised EU rules for online purchases of digital content; the second was referred to somewhat cryptically as 'a focused set of key mandatory EU contractual rights for domestic and cross-border online sales of tangible goods' ${ }^{38}$ The focus of EU action would therefore be on 'online' contracting - both with regard to digital content and tangible goods. One set of rules would deal with the supply of digital content, another with tangible goods. With regard to the latter, the Consumer Sales Directive already covers this area, albeit not with a specific focus on sales contracts concluded online.

The intention is to put into place a set of 'fully harmonised' rules for online contracts for digital content and tangible goods. This could be achieved by following the approach already pursued in the proposal for CESL: utilise a regulation to insert rules dealing specifically with these types of contracts into each domestic law, with the effect that all online contracts would be subject to EU rules. This would basically be a modification of the scope originally given to CESL by (a) limiting it to online contracts but (b) extending it to domestic online contracts (whereas CESL would have been limited to cross-border contracts). This would create a separate set of consumer contract rules for the online/ digital environment, with face-to-face/in-store contracts subject to the national rules implementing the Consumer Sales Directive. It would result in two parallel sets of rules: one for online and another for off-line contracts. As proposed, CESL would also have created two parallel sets of rules, but would have distinguished between cross-border and domestic transactions.

In the end, however, the European Commission has decided to revert to utilising directives to pursue fully harmonised rules on online consumer

38 Single Market Strategy, p. 5. 
sales $^{39}$ and to introduce new rules for digital content. ${ }^{40}$ In its proposals made on 9 December 2015, ${ }^{41}$ it resurrects an approach which failed quite spectacularly with the Consumer Rights Directive, and it is not at all clear whether a further attempt at full, or maximum, harmonisation by directive would succeed. The problems of the harmonisation-by-directive approach are well-known and illustrated by several chapters in this Research Handbook, as already noted. So it will be intriguing to see how successful the European Commission's proposals will be, and how its proposals will be received by legal scholars and politicians alike.

\section{EPILOGUE}

At the time of writing, fresh proposals for action are on the table, but coming so soon after CESL was withdrawn, one cannot help but feel that there has been insufficient time for reflection about fundamental issues regarding the way European contract law should be framed in the future. In particular, attempting full harmonisation by directives, something which has previously failed to gain support from both Member States and commentators alike, is bound to run into difficulties comparable to those encountered with CESL and the Consumer Rights Directive. It seems few, if any, lessons have been learned.

The three concluding chapters ${ }^{42}$ in this Research Handbook highlight very clearly that there are many aspects that have been explored insufficiently, and in respect of which further research is essential. It is hoped that this Research Handbook will encourage legal scholars to consider these and other aspects for their future research in the field of EU consumer and contract law.

39 Proposal for a Directive of the European Parliament and of the Council on certain aspects concerning contracts for the online and other distance sales of goods COM (2015) 635 final, 9 December 2015.

40 Proposal for a Directive of the European Parliament and of the Council on certain aspects concerning contracts for the supply of digital content COM (2015) 634 final, 9 December 2015.

41 These proposals were made after the manuscript for this book had been finalised, and therefore it was not possible to give detailed consideration to these.

42 Chapter 22 (Martijn Hesselink), Chapter 23 (Jacobien Rutgers) and Chapter 24 (Jan Smits). 
Christian Twigg-Flesner - 9781782547372 Downloaded from PubFactory at 04/26/2023 09:57: ๑०AM via free access 